\title{
Koncepce capability approach a její implikace posilující humanitu (nejen) sociální práce Karel Řezáč
}

\begin{abstract}
Abstrakt
V dnešním světě se čím dál víc setkáváme s představami, že úspěch je vyjadřován čísly a materiálním bohatstvím. Hlubší lidské hodnoty jakoby ztrácely na významu a prestiži. Rizika takového stavu jsou patrná na první pohled. Ti, kteří nejsou ekonomicky produktivní, mohou být při honbě za hospodářskou prosperitou vnímáni jako zátěž. Tato ekonomizace, viděno optikou sociální práce, přináší nebezpečí zbavení společenského prostředí zodpovědnosti za péči o sociální rovnost a spravedlivost. Capability approach je koncepcí upozorňující na tato rizika a nabízející humanitní pojetí blahobytu alternativní k současnému pojetí, které můžeme naopak označit za technicistní. Právě proto je v předkládaném článku tato koncepce představena a její interdisciplinární využití předvedeno na příkladu sociální práce, která by vzhledem ke svému cíli měla být předním oborem upozorňujícím na vznikající nerovnosti ve společnosti.
\end{abstract}

Klíčová slova: capability approach, sociální práce, humanita, technicita, kvalita života, blahobyt, lidský rozvoj

\section{Úvod}

Tento článek poskytuje kritický náhled na tendence současné společnosti upřednostňovat technicistní pojetí blahobytu před jeho humanitním pojetím. Text je koncipován jako teoretická studie zabývající se aspekty tohoto stavu společnosti. Cílem studie je nastínit možnosti využití implikací koncepce capability approach do teorie sociální práce. První část nabízí teoretické východisko zmíněného stavu společnosti opírající se o dvě protichůdné dimenze sociálního světa v podobě humanity a technicity, jejichž nerovnovážný stav klade v současné společnosti zvýšené nároky na jednotlivce, které činí stále více zodpovědnými za kvalitu svého vlastního života. Další část představuje koncepci capability approach ve dvou vzájemně souvisejících pojetích jakožto potenciální cestu k posílení humanity společnosti. V poslední části se zabývám tím, jak lze implikace, tedy odvozené závěry z této koncepce, využít v sociální práci jakožto oboru, který by dle svého cíle měl právě humanitu společnosti přinejmenším podporovat a zajistit kvalitu života pro ty, kteří na to sami nestačí. 


\section{Humanita versus technicita}

V našem nitru i ve světě kolem nás se setkáváme s dualitou, která člení řadu aspektů života na kategorie humanitní a technicistní. Humanita představuje souhrn duchovních norem a praktický způsob jednání, které činí člověka člověkem. ${ }^{1}$ Dle Blackburna se dokonce jedná o princip, který ovlivňuje naší interpretaci ve smyslu tendence maximalizovat takové pojetí světa, které vnímá subjekty spíše jako lidsky uvažující než jako pouhé věci. ${ }^{2}$ Pojem humanita tedy vyznačuje podstatu, která činí z člověka lidskou bytost. Nabádá nás uvažovat o světě empatickým způsobem, představovat si sebe sama a své prožívání na místě našeho okolí a současně se k okolí takto chovat. Technicita naopak představuje technologickou kapacitu $\mathrm{k}$ tomu, aby bytí bylo počitatelné a srozumitelné. Technicita je skrze př́rodu a historický vývoj produkována samotným bytím bytostí a vede až $\mathrm{k}$ vypočitatelné proveditelnosti představující machinace, které posilují produktivitu. Technicita tak vychází z minulosti a souvisí s úbytkem těch aspektů, které obvykle vnímáme jako doménu lidskosti. Naopak vyzdvihuje technickou stránku věci s cílem dosáhnout materiální produktivity. ${ }^{3}$ Př́lilšný důraz na technicitu a horečnaté odkrývání exaktní pravdy může vést až k opomíjení samotného bytí, které se takto snaží technicita ovládnout. ${ }^{4} \mathrm{Na}$ jedné straně tak stojí racionalita, materialismus a logika, na druhé straně k nim tvoří opozici emoce, duchovno a tvořivost. Podobné rozdělení najdeme dle slavné lidové dezinterpretace také v lidském mozku. Tento přetrvávající mýtus s největší pravděpodobností vychází z laického pojetí díla neurovědce Rogera W. Sperryho. Ten ve svých studiích objevil odlišnosti v hemisférách lidského mozku a konstatoval, že levá hemisféra ovládá mnoho aspektů jazyka a logiky, zatímco pravá hemisféra zpracovává prostorové informace a vizuální porozumění. ${ }^{5}$ Ačkoliv se později ukázalo, že funkce lidského mozku jsou mnohem složitější, a nelze je tedy striktně rozdělovat do dvou jednoduchých kategorií dle př́íslušnosti $\mathrm{k}$ hemisféře s určitou obecnou vlastností, dal tento objev impulz ke vzniku mylně vytvořené představy, že hemisféry lidského mozku se člení právě v duchu duality humanita versus technicita. Paradoxem je, že pozdější studie dospěly k poznání, že pro obě části mozku je důležitá spolupráce a propojení at při logických úkolech, nebo při proživání emocí. ${ }^{6}$ Ovšem skutečnost, jak právě lidová „tvořivost" přiřkla význam rozdělení mozku, př́hodně odráží tuto dualitu př́tomnou v každém $\mathrm{z}$ nás. Tu dualitu, která může vytvářet protiklady ze slov na první pohled nesouvisejících, jako jsou rozum - emoce, logika - intuice nebo např́klad uvažování představivost.

Dualitu humanity a technicity však nalezneme také na vyšších úrovních lidského života, tedy na úrovni skupin a společenství, jako např. ve vědních disciplínách, pracovních pozicích, politických stranách apod. Tato dualita jako by pokrývala nepřeberné množství úrovní našeho života a vytvářela dvě protichůdné složky lidského bytí. Je třeba ovšem říci, že jakmile jednu z těchto instancí, tedy humanitu či technicitu, nadřadíme druhé, můžeme dojít do extrémních nerovností, kdy na jedné straně nekontrolovatelné nástroje technicistní racionality při střetu s modernitou opomíjeným napětím vedly $\mathrm{k}$ hrůzám a nelidskosti holokaustu, ${ }^{7}$ a na straně druhé např́íklad humanitní

\footnotetext{
Miloslav PETRUSEK, Velký sociologický slovník, Praha: Karolinum, 1996, s. 391.

Simon BLACKBURN, The Oxford Dictionary of Philosophy, Oxford: Oxford University Press, 2016, s. 171.

Martin HEIDEGGER, Mindfulness, London: Continuum, 2006, s. 151-155.

Jiří OLŠOVSKÝ, Slovník filosofických pojmů současnosti, Praha: Vyšehrad, 2018, s. 408-409.

Roger W. SPERRY, Hemisphere Deconnection and Unity in Conscious Awareness, American Psychologist 23/1968, s. 723-733.

(c) Kendra CHERRY, Left Brain vs. Right Brain Dominance: The Surprising Truth. Understanding the Myth of Left and Right Brain Dominance (on-line), dostupné na: https://www.verywellmind.com/left-brain-vs-right-brain-2795005, aktualizace dne 15. 6. 2019, citováno dne 17. 6. 2019. 
všelidové vlastnictví kapitálu původně představující lidskou rovnost, sociální jistoty a snahu zbavit se ideologie, kterou dle Marxe představovala vládnoucí tř́da, vedlo k ekonomickému úpadku, uzavření společnosti a vzniku komunistické diktatury závislé na autoritativním diskurzu. ${ }^{8}$ Ideál jako by se nacházel uprostřed obou těchto dvou entit a vznikal v důsledku jejich vzájemného působení a kontroly jako prevence podobných extrémů výše zmíněných př́kladů. Vždyt pokud hovoříme o holokaustu, probouzí se $\mathrm{v}$ nás právě humanita $\mathrm{v}$ podobě přízně $\mathrm{s}$ obětmi a soucitné lidskosti, zatímco $\mathrm{v}$ př́padě kritiky socialismu se často skloňuje technicita vyjadřovaná argumenty o racionalitě kapitalistické svobody, ekonomických výhodách národní spolupráce, přičemž se obecně uplatňuje kritické uvažování o režimu.

Sociální práce a pomáhající profese jsou obecně v rámci tohoto rozdělení oborem a profesí zastávající svým principem humanitní pojetí. I v rámci této zdánlivě jednoznačné profese se však humanita, zejména ve formě př́stupu k pomoci bližnímu, může na některých místech vyskytovat méně a být pohlcována techniččěǰ́ími prístupy $\mathrm{k}$ práci s člověkem. $\mathrm{Na}$ jedné straně stojí např́iklad Rogersův př́stup orientovaný na klienta, založený na akceptaci a empatickém porozumění bezpodmínečně přijímaného člověka, ${ }^{9}$ zatímco na druhé straně hovoří Musil o procedurálním prrístupu souvisejícím s administrativním pojetím sociální práce, kdy je intervence sociálního pracovníka v podstatě předem (technicky) připraveným řešením situace klienta. ${ }^{10}$ Jak dále uvádí Musil, sociální pracovník je tak pod tlakem př́tomné byrokracie vystavován dilematu, zda obtíže klienta řešit procedurálním nebo situačním př́stupem. Procedurální př́stup můžeme také vnímat jako potenciální nástroj kontroly ze strany politiků a manažerů nad rozhodováním sociálních pracovníků. ${ }^{11}$ Donald Schön tuto procedurální rovinu v kontextu odborných profesí označuje za technickou racionalitu. Ta podle něj zahrnuje kapacitu určitých odborných znalostí či teoretického poznání, kterou praktikující odborník disponuje. ${ }^{12}$ Jako její alternativu uvádí reflexi-při-jednání, která sice představuje určitý kompromis mezi př́lišnou (technicistní) proceduralitou a ryze emocionálním (humanitním) jednáním, avšak tímto implicitně vyjadřuje možnost existence tohoto neprocedurálního a emočního př́stupu k praxi. Takové jednání pak je opozicí k technické racionalitě a představuje čistě praktické zkušenosti a reflektování situace na základě vlastních pocitů oproštěných od profesionálních metod a teorii. ${ }^{13} \mathrm{~V}$ sociální práci, jako humanitním oboru, z principu nastává problém především, pokud technicita převládá nad humanitou. U technických disciplín naopak výraznější obtíž nastává $\mathrm{v}$ př́ípadě, kdy humanita převládne nad technicitou. Př́kladem takové situace může být statik, který při rekonstrukci stavby nedbá na technické výpočty a spoléhá se na své „oko“ profesionála, cit a praktické zkušenosti. Pokud by se jednalo o rekonstrukci psího kotce, patrně by si takové jednání mohl dovolit, ale $\mathrm{v}$ př́ípadě patrové budovy by se jednalo o obrovské riziko. Stejně jako se tento statik nemůže spolehnout pouze na své cítění, nemůže se sociální pracovník soustředit pouze na procedurální postupy a ignorovat tak jedinečný komplex situace klienta. Avšak obdobně jako může humanita v podobě citu a zkušeností statika zefektivnit jeho technicistickou práci, mohou technicistní procedurální postupy zlepšovat výkon humanitní práce sociálního pracovníka.

Patrným důvodem, proč se sociální práce nemůže vymanit z tlaku byrokracie, je to, že se sama opírá o společnost, respektive společenskou solidaritu. ${ }^{14}$ Míra společenské solidarity ovšem

\footnotetext{
Michal PULLMANN, Konec experimentu. Přestavba a pád komunismu v Československu, Praha: Scriptorium, 2011, s. 19-22. Oldřich MATOUŠEK, Encyklopedie sociální práce, Praha: Portál, 2013, s. 20.

10 Libor MUSIL, „Ráda bych Vám pomohla, ale... “Dilemata práce s klienty v organizacích, Brno: Marek Zeman, 2004, s. 110.

11 Tamtéž, s. 110-111.

12 Donald SCHÖN, The Reflective Practitioner: How professionals think in action, London: Temple Smith, 1983, s. 21-49.

13 Tamtéž, s. 49-69.

14 Oldřich MATOUŠEK, Základy sociální práce, Praha: Portál, 2007, s. 10.
} 
pochopitelně není konstantní, nýbrž se přizpůsobuje a mění společně s dobou. Každá doba má totiž své vlastní interpretace společenského dobra a blahobytu, které představují ideál, díky němuž jsou ve společnosti organizovány aktivity reagující na sociální problémy doby. ${ }^{15}$ Bez oněch ideálů by činnost sociálního pracovníka neměla směr. Chyběla by jí totiž představa o zdravém sociálním fungování, tedy o interakcích mezi nároky sociálního prostředí a schopnostmi člověka tyto nároky zvládat. Nerovnováha těchto interakcí je pak předmětem sociální práce. Podpora sociálního fungování je vnímána jako jeden z hlavních cílů sociální práce, překračující dimenzi přístupu či pojetí této profese. ${ }^{16}$ Stejně jako se tedy mění ideály společenského dobra, mění se také nároky prostředí a potažmo i sociální práce.

Vývoj pojetí společenského dobra v naší historii je opravdu pestrý a různorodý. Pro již zmíněného Marxe bylo společenským dobrem všelidové vlastnictví kapitálu, pro Hobbese naopak představa absolutistického státu, pro Stirnera individualistický anarchismus. Co je ovšem ideou dnešního světa? Dnes jsme omámeni ideou pokroku. ${ }^{17}$ Tento pokrok by navíc, jak věří mnozí ekonomové, měl být měřen $\mathrm{z}$ hlediska růstu hrubého domácího produktu společnosti. Ekonomický rozvoj tak zaujal v současné společnosti místo deklarovaného cíle, ba dokonce i reálně uskutečňovaného smyslu bytí jednotlivce a společnosti jako celku. V tomto kontextu výstižně hovoří Samuelson a Nordhaus o tom, že každá doba má své vlastní iluze, přičemž za tu soudobou označují právě víru v sílu ekonomického blahobytu a prosperity. ${ }^{18}$ Společnost jako by opomíjela hodnoty humanity a dualita se na pomyslných vahách nakláněla $\mathrm{k}$ materiálním hodnotám technicity. Někteří odborníci ovšem tento rys dnešní společnosti odsuzují, a to prostřednictvím kritiky politických rozhodnutí. Braber např́klad upozorňuje, že zaměření současné politiky na ekonomický růst ignoruje okolnosti, které mají přímý dopad na obyvatele. Jako příklad uvádí intervence při řešení ekonomické krize, které soustředily úsilí na záchranu hospodářského růstu a finančního trhu, ale zcela ignorovaly dopady, jako je například míra nezaměstnanosti mladých lidí, která v důsledku této krize dosáhla v některých regionech až $60 \% .{ }^{19}$ Potenciálním východiskem z takové situace může být důraz na využití přístupů orientovaných na lidský rozvoj, ${ }^{20}$ tedy prístup zdůrazňující hodnotu humanity. Univerzálním přístupem s širokým uplatněním pro různé rozměry společnosti je právě capability approach.

V kontextu perspektivy sociální práce se „ekonomizace“ odráží v podobě kladení důrazu na výkon a efektivitu jednotlivce. ${ }^{21}$ Tím pak dochází k částečnému popírání pohledu na klienta jako člověka v prostředí, čímž je zároveň popírána psychosociální dualita jeho existence. Role prostředí je totiž vyňata $\mathrm{z}$ komplexu klientovy situace, a v důsledku toho se jednotlivec stává sám odpovědný za svůj život. Takovou optiku si ovšem sociální práce ze svého principu nemůže dovolit a měla by hledat způsoby, jak technicitu vyvažovat zvýšením důrazu na humanitu. Možným způsobem dosažení tohoto stavu může být právě využití přístupu capability approach, jehož princip neopomíjí význam kontextových podmínek lidského bytí, a naopak je staví do popředí. Odklon pozornosti od významu prostředí v kontextu trendu využívání capability approach napříc vědními obory iniciuje myšlenku využití této koncepce také v rámci teorie sociální práce za účelem zvýšení důrazu na humanitu sociální práce a potažmo celé společnosti, navzdory na zisk orientovaným 
ekonomizovaným tendencím dnešní doby. Snahu propojit capability approach a sociální práci vynaložila například Slabbertová, která ve své studii poukazuje na explicitní využitelnost př́stupu při hodnocení blaha klientů. Samotnou aplikaci př́istupu přitom ve výzkumu prováděli studenti sociální práce, kteří prostřednictvím koncepce capability approach dokázali odhalit aspekty způsobující nepohodu klientů na základě předložených kazuistik. Autorka studie proto doporučuje využívání capability approach v sociální práci a také zařazení tohoto přístupu do výuky sociální práce za účelem posílení potenciálu praktických dovedností budoucích sociálních pracovníků. ${ }^{22}$ V oblasti výzkumu sociální práce pak např. Nkhoma a Charnleyová využívají capability approach jako rámec pro kvalitativní výzkum umožňující komplexní odhalení širokého rozsahu různých aspektů problematiky dětské prostituce. ${ }^{23}$ Propojení se tak zdá být nejen možným, ale i vhodným způsobem doplnění sociální práce.

\section{Dva pohledy na capability approach}

Ačkoliv je neoddiskutovatelným autorem capability approach indický ekonom a filozof Amartya Sen, který v této souvislosti dokonce obdržel v roce 1998 Nobelovu cenu za ekonomii, tato koncepce je natolik převratná, že se jí dostalo dalších rozpracování. Za zmínku bezesporu stojí práce Marthy Nussbaumové, která původní spíše abstraktní koncepci transformovala do konkrétnější podoby. Jakoby tedy i zde přetrvávala v první kapitole zmíněná dualita. Přestože se čím dál více přibližujeme humanitnímu smýšlení, i u capability approach jakožto ryze humanitním přístupu k blahobytu nalezneme dvě pojetí, přičemž lze říci, že jedno je více abstraktní a druhé více hmatatelné, čímž jsou opět (ač v nepatrné míře) pomyslně rozlišovány dimenze humanity a technicity. $Z$ tohoto důvodu považuji za vhodné věnovat oddělený prostor oběma těmto pojetím zvlášt a netrvat na jejich bezvýhradné propojenosti v jednotný komplex. Hierarchie je však v tomto ohledu jasná, jelikož Nussbaumová na pojetí Sena explicitně navazuje, představení principu př́istupu capability approach dle Sena je zařazeno do bezprostředně následující kapitoly a v další kapitole je poté podán nástin pojetí Nussbaumové

\section{Pojetí Amartya Sena}

Senova koncepce capability approach vychází převážně z kritiky a revize myšlenek Johna Rawlse a utilitarismu. ${ }^{24}$ Utilitarismus je etickou teorií, jejíž ústřední kategorií je užitek. Mravním kritériem jednání je podle utilitarismu jeho užitečnost při vytváření štěstí. To znamená, že etický význam není motiv nebo úmysl, ale čin a jeho výsledek. Cílem je pak obecné blaho pro všechny, vyjádřené formulí „největší štěstí pro nejvíce lidí“. ${ }^{25} \mathrm{Na}$ základě utilitarismu lze společnost definovat jako spravedlivou, pokud její pravidla podporují dosažení maximálního souhrnu užitku společnosti (tvořenou jedinci a jejich užitky). Problematické je, že spravedlnost ve společnosti je odvozována až z celkového užitku, což vede k nezájmu o jeho rovnoměrnou redistribuci mezi jednotlivými členy společnosti. Za takových podmínek poté může dojít k omezování jedněch ve prospěch druhých ve jménu zvýšení celkové sumy společenského užitku a současně také odlišné

22 Ilze SLABBERT, Applying the capability approach in social work education, Social Work Education 7/2018, s. 867-880

23 Pearson NKHOMA - Helen CHARNLEY, Child protection and social inequality: understanding child prostitution in Malawi, Social sciences 10/2018, s. 185.

24 Amartya SEN, Equality of What?, The Tanner Lecture on Human Values, Delivered at Standford University, 22. 5. 1979, Oxford: Oxford University Press, 1980, s. 198-216.

25 PETRUSEK, Velký..., s. 1361. 
dělbě práv a povinností. ${ }^{26}$ Tato teorie spravedlnosti dle Sena neposkytuje analýzu životních podmínek, které by měly být vnímány jako základní koncept. Perspektiva tohoto pojetí je příliš úzce zaměřena a vylučuje tak hodnocení mnoha dalších důležitých aspektů. Sen ve svých textech naopak vyzdvihuje lidskou individualitu a rozmanitost, která se odráží v neméně rozmanitých individuálních potřebách. Stejné úrovně blahobytu tedy nedosáhneme, pokud budeme potřeby dvou lidí naplňovat stejným způsobem. ${ }^{27}$ Př́ičinu těchto obtíží vnímá Sen mimo jiné v konfliktu rolí lidských bytostí, které jsou na jedné straně př́ijemci pokroku, ale současně na straně druhé také prostředkem jeho dosažení. Tato dvojí role způsobuje zmatení cílů a prostředků při plánování a tvorbě politiky, která se často zaměřuje na produkci a prosperitu jako na podstatu pokroku získanou prostřednictvím lidí místo toho, aby konečnou hodnotnou podstatou byli samotní lidé a jejich kvalita života, vedle které je získávání produkce a prosperity naopak pouhým prostředkem k dosažení takového života. ${ }^{28}$

Ústředním bodem procesu rozvoje je tedy mnohem spíše než ekonomické ukazatele aspekt svobody. Je tomu tak jednak z toho důvodu, že hodnocení pokroku musí být posuzováno především z hlediska rozměru posílení svobody, kterou lidé disponují, a také z důvodu, že dosažení rozvoje je na svobodném pưsobení lidí závislé. ${ }^{29}$ Svobodu Sen dále rozděluje na 5 kategorií tzv. instrumentálních svobod: (1) politické svobody; (2) ekonomické možnosti; (3) sociální příležitosti; (4) záruky transparentnosti; (5) jistota ochrany. Každé z těchto odlišných typů práv a příležitostí pomáhá rozvíjet tzv. potencialitu člověka v obecném smyslu. ${ }^{30}$ Dále je ke správnému porozumění celé koncepce capability approach potřeba rozlišovat dva klíčové prvky, se kterými Sen v teorii pracuje. Jedná se o fungování a již zmíněnou potencialitu (v originále capability). Fungování lze chápat jako rozmanité stavy bytí a činností. Tyto stavy by měly být odlišeny od komodit a zdrojů, které jsou prostředkem $\mathrm{k}$ jejich dosažení (například jízda na kole a vlastnictví kola). Jsou to různé činnosti, stavy či situace, které lidé spontánně považují za důležité a utvářejí lidskou osobnost. Jelikož lidé mají různé hodnoty a zkušenosti, není ve fungování pevně stanovená hierarchie. Dosažené funkce jsou měřitelné, pozorovatelné a srovnatelné, jako např. gramotnost, očekávaná délka života, zdraví, sportovní aktivity atd. ${ }^{31}$ Fungování je v podstatě cílem lidského života, ale může být také prostředkem k dosažení vyššího cíle. Může být jednodušší, jako je vyhýbání se nemoci a úmrtí, opatření stravy, nebo může být složitější, jako sebeúcta, účast ve společnosti, nebo schopnost mluvit na veřejnosti bez pocitu hanby. Fungování může být také obecné, jako např́iklad opatření stravy, nebo může být specifické, jako je možnost konzumace oblíbeného jídla.

Druhý termín, tedy potencialitu, lze chápat v jednotném čísle jako obecnou rovinu lidského bytí, tedy řekněme specifický rys člověka, který je u každého zastoupen v odlišné míře a zjednodušeně představuje souhrn toho, jak svobodný život můžeme žít. Zároveň však můžeme termín nahlížet v množném čísle, kdy jsou jednotlivé potenciality konkrétněji formulovanou svobodou, která je blíže zaměřena na nějaký aspekt lidského života (finance, mezilidské vztahy, bezpečí apod.). Potenciality zahrnují skutečné prŕležitosti, které lidé ve svém životě mají. Potencialita v Senově pojetí představuje svobodu volby ze souboru alternativních životů, které lidé chtějí vést. ${ }^{32}$ Snad nejčastěji užívanou definicí potenciality je: „různá kombinace fungování, kterého člověk může

\footnotetext{
SEN, Equality..., s. 198-199.

Amartya SEN, Inequality Re-examined, Oxford: Clarendon Press, 1992, s. 81-87.

28 Amartya SEN, Development as Capability Expansion, in: Readings in Human Development, ed. Sakiko FUKUDA-PARR - A. K. Shiva KUMAR, New Delhi and New York: Oxford University Press, 2003, s. 41.

29 Amartya SEN, Development as Freedom, New York: Knopf, 1999, s. 4.

30 Tamtéž, s. 10

31 SEN, Development as Capability..., s. 43-44.

32 BRABER, The introduction..., s. 67-68.
} 
dosáhnout“, 33 nebo také: „sada vektorů fungování, které odráží svobodu člověka vést určitý (zvolený) typ života“. ${ }^{44}$ Obě tyto definice vychází z původní teorie Amartya Sena. Ten sám vymezil potenciality jako soubor hodnotných fungování, která má člověk důvod považovat za hodnotná a ke kterým má efektivní př́stup. ${ }^{35}$ Představují tedy skutečnou svobodu jednotlivce volit si mezi různými kombinacemi fungování, neboli vybrat si svou vlastní životní cestu. Vedle míry svobody jednotlivce jakožto garance lidského rozvoje proto musíme zmínit také prvek volby, který je rovněž podstatnou součástí celé koncepce. Svobodnou volbu Sen v podstatě implicitně podmiňuje obousměrným vztahem mezi participací lidí na svém rozvoji a veřejnou politikou zohledňující význam potenciality. ${ }^{36}$

Souhrnně můžeme říci, že koncepce capability approach usiluje o takové uspořádání společnosti, které nehodnotí míru rozvoje na základě technicistních ekonomických indikátorů, ale zaměřuje se v tomto směru na humanistické ukazatele lidského potenciálu a kvalitu života podmíněnou reálnou př́ležitostí žít takový život, jaký jednotlivec chce. Členové takové společnosti mají možnost uskutečňovat svobodné volby z dostatku potencialit jakožto reálných př́ležitostí k dosažení fungování dle vlastní individuální determinace. Je třeba také zmínit, že Amartya Sen je někdy kritizován za to, že jeho koncepce je příliš obecná a Sen sám nenabízí ve svých textech př́klady praktického využití capability approach v praxi. ${ }^{37}$ Nutno ovšem také podotknout, že patrně i díky této skutečnosti je koncepce velmi variabilní a našla své interdisciplinární uplatnění v celém spektru dalších oblastí, zejména v rámci sociálních věd. ${ }^{38}$ Jedno z nejvýznamnějších rozpracování, které velmi explicitně navazuje na Senovy myšlenky, nabízí právě výše zmíněná Martha Nussbaumová. Ta se v kontextu lidských práv zaměřila na konkretizaci jednotlivých hlavních lidských potencialit.

\section{Pojetí Marthy Nussbaumové}

Významné přispění americké filozofky Marthy Nussbaumové pro koncepci capability approach spočívá zejména v tom, že na základě myšlenek Amartya Sena sestavila univerzální seznam deseti hlavních lidských potencialit. Celý koncept tak z původního nástroje měření blahobytu upravuje na konkrétnější normativní rámec, jenž by měl být pro obyvatele vymahatelnou součástí legislativy všech států, jelikož se jedná o nepostradatelné podmínky lidské důstojnosti. ${ }^{39}$ Tyto hlavní potenciality musí být ve společnosti zajištěny alespoň v určité minimální míře každému $\mathrm{z}$ jejích členů. Pokud tomu tak není, společnost nenaplňuje hodnotu sociální spravedlnosti. ${ }^{40}$ Autorka tedy perspektivou kontextu duality humanita versus technicita kombinuje obě tyto dimenze tím, že provádí technicistní aplikaci humanitních východisek.

Konkrétní seznam hlavních lidských potencialit je následující: (1) život: možnost žít hodnotný lidský život do jeho konce v běžné délce, předcházet riziku předčasného úmrtí a znehodnocení života; (2) tělesné zdraví: příležitosti dobrého zdraví, včetně zdraví z hlediska reprodukce, adekvátní výživa, péče a zajištění přístřreší; (3) tělesná integrita: možnost volně se pohybovat

33 Sabina ALKIRE - Séverine DENEULIN, The Human Development and Capability Approach, in: An introduction to the Human development and Capability Approach, ed. Séverine DENEULIN, Lila SHAHANI, London: Earthscan, 2009, s. 31.

34 Sabina ALKIRE, Why the capability approach?, Journal of Human Development 6/2005, s. 121.

35 SEN, Development as Freedom..., s. 18.

36 Tamtéž.

37 Martin EHL, Rozvojové země a trh trochu jinak, Mezinárodní vztahy 1/2000, s. 108.

38 @ Ingrid ROBEYNS, The Capability Approach (on-line), dostupné na: https://plato.stanford.edu/entries/capability-approach, aktualizace dne 3. 10. 2016, citováno dne 28. 6. 2019.

39 Martha NUSSBAUM, Women and Human Development, New York: Cambridge University Press, 2000, s. 5-13.

40 Martha NUSSBAUM, Capabilities as Fundamental Entitlements: Sen and Social Justice, Feminist Economics 9/2003, s. 41-42. 
z místa na místo, ochrana před násilným napadením, včetně sexuálního napadení a domácího násilí, prŕležitosti k sexuálnímu uspokojení a volbám v oblasti reprodukce; (4) smysl, představivost a myšlení: schopnost používat smysly, představivost, přemýšlení a rozum a možnost dělat tyto činnosti „skutečně lidským“ způsobem, tedy informovanou a kultivovanou cestou, která je zajištěna dostupným a adekvátním vzděláním, schopnost svobodně používat tvořivou představivost i v rámci duchovna a umění, možnost používat svou mysl způsoby zaštítěnými zárukami svobody projevu s ohledem i na politický a umělecký projev a svobodu náboženského vyznání, mít možnost příjemných zážitků, vyhnutí se nepř́ijemnostem a bolesti; (5) emoce: možnost mít citové pouto k věcem a lidem ve svém okolí, milovat ty, kteří milují nás a starají se o nás, truchlit nad jejich nepřítomností, milovat, truchlit, prožívat touhu, vděčnost a oprávněný hněv v obecném smyslu, možnost vyvarovat se takovému rozvoji, který by byl mařen strachem a úzkostí; (6) praktické uvažování: schopnost formulovat určitá pojetí dobra a zapojovat se do kritické úvahy o plánování vlastního života (což v sobě zarhnuje ochranu svobody svědomí a náboženských zvyklostí); (7) vztahy: (a) možnost žít s ostatními a ve vztahu s nimi, rozpoznávat a projevovat zájem o jiné lidské bytosti, zapojovat se do různých forem sociální interakce, být schopen soucitu a empatie; (b) mít sociální rámec pro vytváření sebeúcty a nebýt ponižován, schopnost být považován za důstojnou bytost, jejíž hodnota se rovná hodnotě ostatních, nebýt diskriminován na základě rasy, pohlaví, sexuální orientace, etnicity, kasty, náboženství, národnosti; (8) jiné druhy: být schopen žít se zájmem o zvírata, rostliny a svět přírody a mít možnost vztahu k nim; (9) hra: mít možnost smát se, hrát si a těšit se z volnočasových aktivit; (10) kontrola nad svým prostředím: (a) politická: schopnost účinně se účastnit politických rozhodnutí, kterými se řídí život člověka, mít právo na politickou účast, ochranu svobody projevu a sdružování; (b) materiální: schopnost vlastnit majetek (movitý i nemovitý), disponovat majetkovými právy ve stejné míře jako ostatní, mít právo usilovat o zaměstnání na základě principu rovnosti s ostatními, být chráněn před neoprávněným pronásledováním a zbavením vlastnictví. ${ }^{41}$ Toto jsou tedy základní lidské potenciality, respektive jiným označením též capability, schopnosti, možnosti apod., které by měli mít zajištěny všichni členové společnosti, má-li být tato společnost uznána za sociálně spravedlivou.

\section{Využití capabillity approach v sociální práci}

Teoretická východiska capability approach jsou díky svému hodnotovému pozadí a uplatňovaným principům aplikovatelná také pro teorii sociální práce a pomáhajících profesí. V současné koncepci lidského blahobytu i sociální práce a dalších př́ibuzných oborů má klíčové postavení pojem sociální fungování. ${ }^{42}$ Tento pojem můžeme vnímat jako společný základ při vymezování kvality života. Podle Navrátila a Musila je sociální fungování klíčem k pochopení specifické optiky sociální práce. ${ }^{43}$ Užívání termínu sociálního fungování již přesáhlo hranice určité teoretické školy či specifického modelu sociální práce. Podpora sociálního fungování začala být totiž vnímána rovněž jako jeden z hlavních cílů sociální práce coby specifické profese. ${ }^{44}$ Označuje schopnost lidí zvládat očekávání prostředí. Lidé jsou dle této perspektivy v neustálé interakci s prostředím.

41 Martha NUSSBAUM, Creating Capabilties: The Human Development Approach, Cambridge, MA: Harvard University Press, 2011, s. 33-34.

42 Zuzana PALOVIČOVÁ, K pojmu sociálneho fungovanie, FILOZOFIA 9/2011, s. 833.

43 Pavel NAVRÁTIL - Libor MUSIL, Sociální práce s příslušníky menšinových skupin, in: Sborník prací fakulty sociálních studií brněnské univerzity, Sociální studia č. 5, Brno: Fakulta sociálních studií, 2000, s. 118.

44 NAVRÁTIL, Reflexivní..., s. 50. 
Za běžných okolností je interakce v rovnováze. Pokud lidé požadavky prostředí dostatečně nezvládají, rovnováha je rozkolísána a vzniká problém. ${ }^{45}$ Tato nerovnováha je pak prostorem pro intervenci sociální práce, která může bud' usilovat o posílení sociálního fungování klienta, regulovat očekávání prostředí, nebo směřuje k posílení interakce.

Zacílení intervence v tomto smyslu do značné míry vychází ze zvoleného přístupu sociální práce. Tyto přístupy diferencuje Navrátil na základě teorie Payna do tří základních paradigmat, později nazývaných jako typické přístupy sociálních pracovníků. Jedná se o: (1) terapeutický přístup; (2) poradenský přístup; (3) reformní přístup. ${ }^{46}$ Výhodou těchto paradigmat, respektive př́istupů je, že zobecňují širokou škálu různých a odlišných přístupů sociální práce do tří kategorií, které v rámci tohoto trojího členění sdružují jejich nejpodstatnější společné znaky a princip, o který se opírají. Jako nevýhodu využití tohoto modelu však můžeme vnímat právě ono zobecnění, které nás odvádí od konkrétních a detailních specifik jednotlivých přístupů, a brání tak úplné univerzalitě. Každý z těchto obecných přístupů, respektive sociální pracovník jednající podle něj pojímá zajištění rovnováhy z jiné perspektivy. Terapeutický př́istup se zaměřuje na duševní zdraví a pohodu člověka jako předpoklad zdravého sociálního fungování, poradenský prrístup na schopnosti zvládat problémy a př́istup k odpovídajícím informacím a službám a reformní přístup na společenskou rovnost $\mathrm{v}$ různých dimenzích společenského života. ${ }^{47}$ Pojetí praxe se pak v rámci jednotlivých př́ístupư liší společně s odlišným diskurzem. Diskurz můžeme interpretovat jako princip a společensky uznávanou normu utváření smyslu sdělení v určitém konkrétním užití, tedy sdělení s atributem. ${ }^{48} \mathrm{~V}$ případě terapeutického př́ístupu se tak pohybujeme zejména $\mathrm{v}$ psychologickém diskurzu, u poradenského př́stupu zase v právním diskurzu a reformní přístup svým zaměřením nejvíce odpovídá diskurzu politickému. Podoba intervence se následně se zvoleným přístupem a diskurzem liší a postup sociálních pracovníků je pochopitelně v tomto důsledku odlišný. Model lze rozšírit také o úrovně sociální práce: (1) mikro; (2) mezzo; (3) makro. Termín mikro praxe označuje aktivity, které pomáhají řešit problémy jednotlivcům. Do úrovně mezzo praxe zahrnujeme sociální práci s rodinami a skupinami a makro praxe se zaměřuje na zlepšování sociálních podmínek a změny v celé společnosti. Zahrnuje tedy aktivity, jako jsou politické akce, komunitní plánování, veřejné vzdělávací akce apod. ${ }^{49}$ Obecně lze říci, že terapeutický přístup se týká zejména mikro praxe sociální práce, poradenský prrístup mezzo praxe a reformní přístup především makro praxe sociální práce. Tímto způsobem lze teoreticky popsat všestranné spektrum činností sociální práce.

Implikace vycházející z koncepce capability approach v prvé řadě souvisí s nahlížením na pojem očekávání. Z hlediska psychologie je pojem očekávání možno diferenciovat do dvou odlišných forem. V anglickém jazyce můžeme odlišnost spatřit i z lingvistického hlediska, nebot očekávání může být ve významu slovo expectation, ale zároveň, v trochu jiném smyslu, jej vyjadřuje také výraz expectancy. První z výrazů (expektace) představuje očekávání ve smyslu předpokladu či pocitu nebo předpovědi vycházející zejména ze zkušenosti člověka. Pojem expectancy (expektance) lze do češtiny rovněž přeložit jako očekávání, avšak v tomto smyslu již předpoklady nejsou toliko podloženy zkušenostmi, nýbrž intuicí opírající se spíše o víru a naději, že budoucnost bude taková, jakou si ji člověk přeje. Charakter tohoto očekávání je

\footnotetext{
5 NAVRÁTIL - MUSIL, Sociální..., s. 118.

6 Tamtéž, s. 121

7 Tamtéž, s. 121-123.

48 Jiří KRAUS, Rétorika a řečová kultura, Praha: Karolinum, 2010, s. 18.

49 Cindy GARTHWAIT, Dictionary of Social Work, Missoula: The University of Montana, 2012, s. 12.
} 
pozitivní a dalo by se říci i inovativní, jelikož s sebou přináší představu o tom, jak by očekávané mělo vypadat podle představ jeho nositele..$^{50}$ Pro lepší názornost uvedu př́klad odhalující tuto dvojznačnost českého jazyka. Pokud u pracovního pohovoru dostanete otázku: „Jaká jsou vaše očekávání od pracovní pozice, o kterou se ucházíte?", odpovědí ve smyslu významu expektace bychom před budoucím zaměstnavatelem prokazovali své znalosti o tom, jaký máme přehled o skutečné náplni dané profese, o tom, jaké úkoly nás čekají, at již jsou pro nás jako jejich budoucí vykonavatele př́ijemné či nepříjemné. Pokud bychom si vyložili slovo ve významu slova expektance, začali bychom hovořit o tom, co by nám podle našich představ mohla práce přinést, čím bychom mohli pozici obohatit my, proč věříme, že je pro nás právě tato pracovní př́ležitost vhodná apod.

Právě prostřednictvím této dvojznačnosti lze porozumět tomu, jak koncepce capability approach odlišně pohlíží na sociální interakce člověka s prostředím. Zatímco perspektiva sociální práce pojednává o očekávání (expektaci) jako o sociálním konstruktu společnosti, který přisuzuje vyžadované sociální fungování určitým rolím, v případě capability approach je očekávání (expektance) pojímáno jako představa člověka o tom, jak by jeho sociální fungování mělo vypadat, respektive jak by sám chtěl naplňovat své sociální role. Život podle vlastní svobodné volby na základě zajištěných potencialit, které toto umožňují, tak představuje výzvu pro sociální práci nespokojit se s tím, že sociální pracovníci pomáhají klientům žít život, jaký od nich očekává společnost, ale také žít co možná nejpřijatelněji život, jaký očekávají klienti od sebe samotných.

Pokud budeme na sociální práci pohlížet perspektivou capability approach, je nasnadě zvažovat, jak jednotlivé přístupy a úrovně sociální práce pojímají zajištění potencialit. Zjednodušeně lze předpokládat, že diskurzy jednotlivých př́ístupư částečně omezují rozhled sociálního pracovníka při hledání řešení, jak zajistit klientovi potenciality. Dimenze potencialit, jakožto prvku spojujícího přání, potřeby či očekávání klienta s jejich reálným životem, v podstatě vymezuje pole působnosti intervence sociální práce. Jelikož je intervence na základě zvoleného př́stupu sociálního pracovníka podřízena odpovídajícímu diskurzu daného přístupu, může sociální pracovník v tomto důsledku vybírat (a poté klientovi zprostředkovávat) zčásti omezené cesty k zajištění sociálního fungování. Tato skutečnost může být způsobena př́lišnou orientací sociálních pracovníků na obtíže a (vy)řešení situace, přičemž po doplnění takové praxe o rozměr klientem akceptovaného řešení není věnována pozornost řešením jiným. Rozšírení sociální práce o myšlenky vycházející z capability approach přisuzuje větší význam volbě způsobu řešení nepř́íznivé situace klienta, díky čemuž může být problém vyřešen efektivněji, komplexněji a především s mnohem větším zájmem a zapojením klienta. Jinými slovy tak koncepce capability approach může propojovat jednotlivé přístupy sociální práce, jelikož je předpokladem jejich variabilních kombinací při hledání možností různě orientovaných řešení situace klienta.

Konkrétní seznam lidských potencialit pak může sociální práci nabízet nový, komplexnější pohled na situaci klienta. Může napomoci ke snadnějšímu a přehlednějšímu identifikování zdrojů problému. Rozšiřuje tedy pojetí hodnocení situace klienta, jaké známe například z praxe sociálně-právní ochrany dětí. ${ }^{51}$ Konkrétní potenciality představují zejména pro oblast sociální politiky, reformního př́stupu a makro praxe sociální práce model ukotvující cíl směřování

50 Srov. Mallappa BASAVANNA, Dictionary of Psychology, New Delhi: Allied Publishers, 2000, s. 139; Raymond J. CORSINI, The Dictionary of Psychology, New York: Routledge, 2016, s. 351; David MATSUMOTO, The Cambridge Dictionary of Psychology, Cambridge: Cambridge University Press, 2009, s. 193.

51 C MPSV ČR, Informace k vyhodnocení situace dítěte (on-line), dostupné na: https://www.mpsv.cz/files/clanky/14230/vyhodnocovani. pdf, citováno dne 29. 6.2019. 
politiky k zajištění sociální rovnosti. Mưže sloužit k vyhodnocení stavu části společnosti a strategickému plánování sociálních služeb. Tato koncepce představuje směr a oblasti pomoci potřebným lidem získat adekvátní kvalitu života. Možným nástrojem pro pomoc se zajištěním této kvality života i u těch, kteří na to sami nestačí, je následně opět sociální práce.

\section{Závěr}

Může se zdát, že hledání způsobu, jak činit sociální práci ještě více humanitní, je vzhledem k jejímu původnímu hodnotovému východisku zbytečné. Je třeba si ovšem uvědomit, že i kdyby sociální práce zůstala nedotčena dobovým trendem přisuzovat hodnotu technicistnímu blahobytu (což se jeví přinejmenším jako nepravděpodobné), sociální pracovníci by bezesporu měli být těmi prvními, kdo začnou na tento společenský jev upozorňovat, jelikož právě v jejich praxi se takové společenské trendy nejvíce projeví. Capability approach je jednoznačně koncepcí s velmi širokou škálou možného uplatnění, oblasti sociální práce nevyjímaje.

Koncepce rozvíjí pojetí rovnováhy mezi sociálním fungováním člověka a očekáváním jeho prostř̌edí o rozměr vlastních vnitřních očekávání člověka od sebe samotného. $V$ rámci pojetí typických př́stupů sociální práce poskytuje capability approach (respektive prvek potencialit) doplnění přístupů o zaměření se na hledání množiny možných multidiskurzivních a komplexních řešení nepřínivé situace klienta, a zamezuje tak nejednotnosti a rozdílnostem odlišných přístupů. Tím umožňuje efektivnější, vědomější a svobodnější řešení klientovy situace skrze jeho vlastní svobodnou volbu ze škály dostupných řešení.

V praxi by tak sociální pracovníci, jednající dle principu capability approach, především vyjednávali cíl intervence společně s klientem pomocí dialogu vytvářejícím konfrontaci klienta s očekáváními, jaká jsou na něj v jeho situaci a roli kladena sociálním prostředím. Zároveň by však při tomto dialogu mapovali očekávání samotného klienta, tedy jak by jeho situace měla být řešena a role naplňována dle jeho představ. Stanovený cíl by konečně měl mít podobu kompromisu mezi očekáváním prostředí a očekáváním klienta. Při hledání způsobu dosažení cíle by nato měl $\mathrm{v}$ př́ípadě využití tohoto př́stupu sociální pracovník hledat a nabízet alternativní cesty $\mathrm{k}$ jeho dosažení. Z těchto možných cest by následně klient svobodně volil tu, po které se $\mathrm{k}$ cíli chce vydat. Jednotlivé potenciality zase mohou posloužit za výchozí podklad pro komplexní posouzení životní situace klienta, které zohledňuje různé kontextuální aspekty jeho situace. Mohou být též východiskem pro hodnocení rovnosti odlišných členů či skupin ve společnosti a tvořit kriteriální základ pro deklaraci jejich práv. Zajištění potencialit lze rovněž využít jako indikátor toho, zda došlo ke komplexnímu dosažení cíle intervence sociálního pracovníka. Naplnění potencialit by poté mohlo obecně definovat hranici sociální práce, respektive i vymezit její cíl v podobě zajištování potencialit. Problémem však zůstává otázka, do jaké míry mají být potenciality zajištěny a $\mathrm{v}$ jakém konkrétním případě lze určit potencialitu za zajištěnou. Capability approach tak může inspirovat sociální práci k uznání významu klientovi možnosti svobodné volby z nabízejících se cest, jak společností kladená očekávání naplňovat. Místo pro sociální práci pak bude vždy tam, kde podnětem pro př́ležitost k takové volbě jsou limity, nerovnost a nespravedlnost. Obě koncepce se jeví jako dobře kompatibilní. Sociální práce může být také chápána jako nástroj pomáhající vyrovnat nerovnosti a naplnit nenaplněné potenciality, které lze identifikovat právě pomocí capability approach coby hodnotícího rámce. Nabízí ovšem koncepce capability approach natolik výrazný a jedinečný způsob uvažování o sociálních jevech, aby byla $\mathrm{v}$ budoucnu pevně transformována do podoby metody či teorie sociální práce? Ač tomu mnoho ukazatelů nasvědčuje, stále je před námi daleká cesta, na jejímž konci 
však může být sociální práce bohatší o přístup, který inovativním a novým způsobem podporuje humanitu této profese a jejích klientů.

\section{Kontakt na autora}

Mgr. Karel Řezáč

Západočeská univerzita v Plzni

Fakulta filozofická, Katedra sociologie

Sedláčkova 15, 30100 Plzeň

rezack@kss.zcu.cz 